\title{
The Effect of Filter Ventilation on the Yield and Composition of Mainstream and Sidestream Smokes*
}

\author{
by C. L. Browne, C. H. Keith and R. E. Allen \\ Celanese Fibers Company, Charlotte, North Carolina, U.S.A.
}

\section{INTRODUCTION}

In recent years, there has been an increase in the use of ventilation in the design of cigarettes. This is most apparent in the case of ventilated filter cigarettes. With this type of cigarette, it is possible to achieve major reductions in all smoke components including those in the gas phase. However, as found by Norman (5) and by Morie (8), the effects of ventilation are not entirely those of a straight dilution of the smoke, as some components are relatively enhanced and others relatively decreased in the effluent smoke stream. It therefore seemed desirable to investigate the interaction between filter ventilation and the combustion process occurring in the tobacco portion of the cigarette. Since sidestream smoke is a major portion of the total smoke stream, we also investigated the effects of filter venting on sidestream smoke yields to provide information on the total smoke yield and as to whether reductions in the mainstream caused an increase in sidestream deliveries.

The effect of cigarette paper porosity on the smoking characteristics and particulate yield of cigarettes was studied by Schur and Rickards (1). Their work showed the effect of paper porosity, burn rate and nature of the paper ash on puff count and yield of particulate matter from unfiltered cigarettes. These authors recognized the effect on particulate yield and puff count of the relative amounts of tobacco consumed in free burn during the puff interval and during the puff itself. Lipp and van Nooy (2) reported the effect of paper porosity on the puff count, dry condensate and nicotine yields of filtered cigarettes. In this work also, it was recognized that less tobacco was consumed per puff as a result of ventilation through the porous paper. The reductions in dry condensate and nicotine agreed well with the level of paper ventilation. In a more extensive study, Müller, Neurath and Horstmann

\footnotetext{
* Presented at the 32nd Tobacco Chemists' Research Conference held in Montreal, Canada, in November 1978.

Received: 23rd March 1979 - accepted: 12th November 1979.
}

(3) were able to interpret the effects of cigarette paper porosity in terms of the relative amounts of tobacco consumed in generating the mainstream and sidestream. They also established that the amount of condensate and nicotine generated per unit weight of tobacco consumed remained essentially unchanged over the range of paper porosity studied. It was also found that the amount of sidestream nicotine increased and mainstream nicotine decreased with increased ventilation from the use of porous paper.

The distribution of water between the mainstream and sidestream was examined for unfiltered cigarettes by $\mathrm{Neu}$ rath, Ebmke and Schneemann (9). The experiments of Jobnson et al. (4) included the determination of the mainstream/sidestream distribution of a number of smoke components. They were able to explain much of their data on the basis of either the volatility of the compound or the thermal conditions required for its formation. Norman (5) studied the effect of filter ventilation on the mainstream deliveries of a number of smoke compounds. His studies extended over degrees of ventilation ranging from $20 \%$ to $70 \%$. In comparing measured deliveries with deliveries expected from the degree of ventilation, some compounds were reduced more than predicted (carbon monoxide, hydrogen cyanide) while others were reduced less than predicted (phenols and nicotine). The deviations from expected behavior are attributed to various causes such as volatility and changes in combustion with ventilation.

Several studies have been published by Morie $(6,7,8)$ in which he noted unexpectedly large reductions in carbon monoxide with ventilated filter cigarettes. The amount of reduction over and above that predicted from the degree of filter ventilation is attributed to increased outward diffusion of carbon monoxide relative to carbon dioxide at the lowered flow rate (8). No change in the combustion process is proposed.

It is our purpose to report information showing the effect of a range of filter ventilation on the principal mainstream and sidestream combustion products and to propose an explanation for the phenomena observed. 
Figure 1. Sketch of smoking chamber.

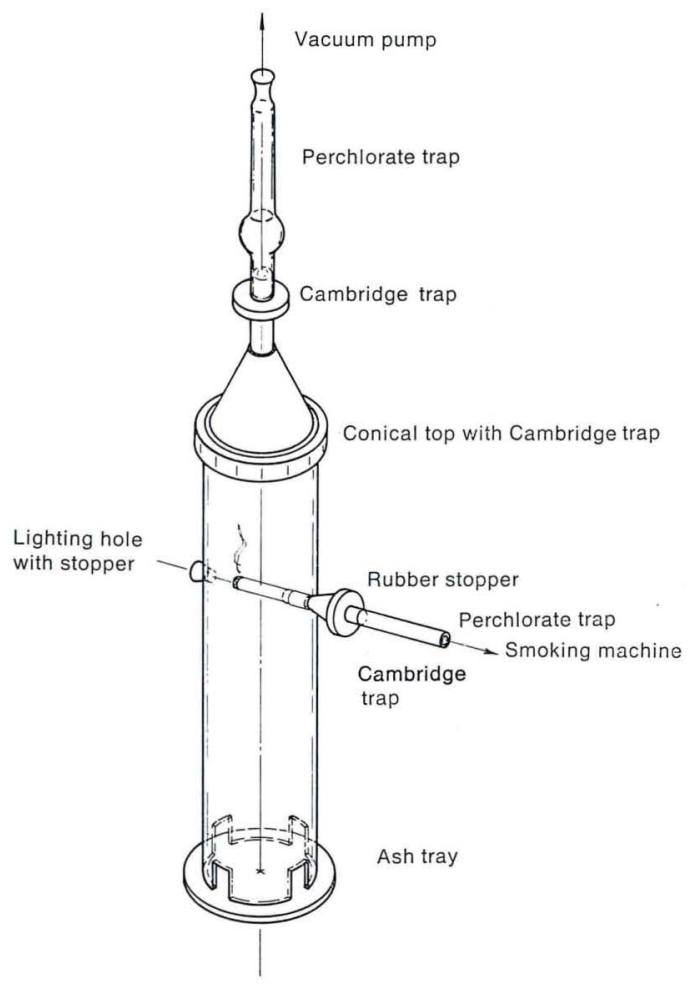

\section{EXPERIMENTAL AND APPARATUS}

\section{Smoking Chamber}

Figure 1 is a sketch of the smoking chamber. This apparatus is similar to that described by Jobnson et al. (4). The chamber was made from $10.2 \mathrm{~cm}$ outside diameter $\times 8.9 \mathrm{~cm}$ inside diameter $\times 41.5 \mathrm{~cm}$ Plexiglas tubing with bottom holes to allow vertical, non-turbulent air flow. The tubing was threaded so that a conical screw cap could be attached without air leaks. This cap was made from a polyethylene jar top and a polyethylene funnel cemented together. A standard Petri dish set at the bottom of the chamber was used as an ash tray. A circular hole was cut in the side of the chamber (10 $\mathrm{cm}$ from the top) to allow a cigarette to protrude into the chamber. The position of this hole was fixed so that no smoke could be seen falling below the level of the cigarette at any time. A hole was drilled opposite the cigarette hole to allow the lighting of the cigarette inside the chamber. A rubber stopper was used to close this hole after lighting.

\section{Collection of Mainstream Smoke}

For the collection of mainstream particulate matter, a cigarette was attached to a standard Cambridge trap (4.3 $\mathrm{cm}$ diameter pad) with a latex sleeve and passed through a rubber stopper which fitted snugly on the neck of the trap but not the cigarette. This stopper provided an airtight seal when the cigarette was placed into the smoking chamber. A glass tube $(0.7 \mathrm{~cm}$ inside diameter $\times 10.5 \mathrm{~cm})$ filled with magnesium perchlorate (G. Frederick Smith Chemical Co.) was placed in series with the Cambridge trap. This trapped the vapor phase water and nicotine which passed through the Cambridge trap. The magnesium perchlorate was held in place with glass wool. This tube was connected to a Filamatic Vial Filler piston-action smoking machine which was adjusted to take a $35 \mathrm{~cm}^{3}$ puff of 2 seconds duration once per minute. The exhaust from the smoking machine to be used for the measurement of carbon monoxide and carbon dioxide was collected in a 21 surgical respirator bag with a 2 -way valve. Either latex or rubber was used for all connections except that Tygon was used to connect the mainstream perchlorate trap to the smoking machine.

\section{Collection of Sidestream Smoke}

Two Cambridge traps were used for the collection of sidestream particulate matter. A large pad $(9.3 \mathrm{~cm}$ diameter) was put on top of the chamber and held in place by the conical cap. A small Cambridge trap ( $4.3 \mathrm{~cm}$ diameter pad) was connected to the neck of the conical cap. Two drying tubes $(\sim 1.4 \mathrm{~cm}$ inside diameter $\times 17 \mathrm{~cm})$ filled with magnesium perchlorate to trap sidestream vapor phase water and nicotine were connected in series with the Cambridge pads. The perchlorate was held in place with glass wool. The exit of the second drying tube was connected to a bellowstype vacuum pump (Gelman Little Giant Model 13154) which moved the air through the smoking chamber. For the masurement of sidestream carbon monoxide and carbon dioxide, the exhaust from the pump was collected in a 1801 gas sampling bag (Altech Associates Model 4146) with a two-way valve. The flow rate of air was set prior to each experiment to be $5.9 \mathrm{l} / \mathrm{min}$. This rate was chosen so that the puff count, mainstream condensate, nicotine, carbon monoxide and carbon dioxide deliveries using the chamber would approximate that obtained using a standard smoking machine with no smoking chamber. Any extraordinary effect of the chimney on combustion was avoided by the choice of flow conditions. The flow was monitored throughout smoking by means of the pressure gauge on the pump. The resultant air speed $(1.58 \mathrm{~cm} / \mathrm{s})$ is not high enough to affect the outward diffusion of $\mathrm{CO}$ significantly (15).

\section{Preparation of Cigarettes}

All of the cigarette columns and filters used were conditioned at least 48 hours at $74 \pm 2{ }^{\circ} \mathrm{F}$ and $60 \pm 2 \%$ relative humidity before undergoing selection. The columns were made from a typical U.S.A.-type tobacco blend using Ecusta 556 paper. They were cut to $60 \mathrm{~mm}$ lengths and then weight selected. The $25 \mathrm{~mm}$ ventilated filters used were obtained from commercial cigarettes purchased at local stores. The filters were selected by pressure drop and used without modification for ventilated experiments. For non-ventilated experiments the ventilation holes were covered with non-porous tape. The filters were attached to the columns with cellophane tape. The cigarettes were smoked to $33 \mathrm{~mm}$ butt lengths in the standard conditioned atmosphere. Filter ventilations were calculated using the pressure drop method of Keith(14). Ventilation calculated 
in this way using an unlit cigarette is somewhat lower than for the lit cigarette, but this should not influence the main conclusions.

\section{Smoke Analyses}

Cambridge particulate matter (CPM) and water and nicotine in CPM were determined according to a protocol described in a study by Ogg and Schultz (10). CPM was determined gravimetrically, water by gas chromatography of the isopropanol extract of CPM, and nicotine by spectrophotometry of the steam distillate of the isopropanol extract of CPM. Particulate matter, water, and nicotine in the filters were determined in the same manner as for the Cambridge pads.

The sum of vapor phase water and vapor phase nicotine for both mainstream and sidestream was determined by the weight gain of the magnesium perchlorate traps. This weight gain was corrected for the water absorbed from the atmosphere. However, the relatively large size of the atmospheric water blank makes the estimation of sidestream water less accurate. Nicotine was determined in the sidestream perchlorate trap by dissolving the contents of the trap and steam distilling an aliquot of the resulting solution followed by spectrophotometry. At least $90 \%$ of the vapor phase nicotine was collected in the first perchlorate trap. The entire contents of the mainstream perchlorate trap were steam distilled. The weight gains of the trap minus the nicotine absorbed yielded the vapor phase water results.

Mainstream carbon monoxide and carbon dioxide were determined by gas chromatography using a reactive column described by Watanabe and Kobashi (11). The sample was introduced into the chromatograph by attaching the respirator bag to a gas sampling valve on the chromatograph. Sidestream carbon monoxide and carbon dioxide were determined also by gas chromatography but separate columns were used (Molecular Sieve 5A for carbon monoxide and silica gel for carbon dioxide). A gas syringe was used to introduce the sidestream samples into the gas sampling valves on the chromatograph.

\section{RESULTS AND DISCUSSION}

The data collected for the mainstream particulate phase are given in Table 1. All data given in the tables are the average of at least two determinations. The amounts of condensate*, nicotine and water collected on the filter are included in the mainstream total for the purposes of this paper. Using the standard puff cycle at increasing levels of dilution produces a steady decrease in deliveries of particulate phase components: total particulate matter (TPM), water, nicotine and condensate. These decreases can be predicted from the decreases in the puff volume at the coal resulting from the filter ventilation (12). To confirm the importance of puff volume at the coal, cigarettes were smoked using low $(17.5 \mathrm{ml})$ and high $(50 \mathrm{ml})$ puff

" "Condensate" refers to total particulate matter less nicotine and water. volumes with and without $33 \%$ filter ventilation. Puff duration was held constant at two seconds. In three of the four cases where similar puff volumes at the coal were arrived at by other combinations of exit puff volume and filter ventilation, there was good correlation between mainstream particulate phase deliveries and puff volume at the cone. However, the results for an undiluted $17.5 \mathrm{ml}$ puff appear to be anomalous.

The mainstream vapor phase data are given in Table 2 in the same format as the mainstream particulate phase data in Table 1. Here, also, there is a steady decrease in most component deliveries: carbon monoxide, carbon dioxide and nicotine. The vapor phase water delivery shows a downward trend with ventilation, but is not as clear. In the cases of nicotine and water, butt filtration may be playing a significant role. The correlation of vapor phase delivery with puff volume is also apparent in this case, with the exception of the same anomalous experiment.

Plots of regression equations derived from the mainstream data given in Tables 1 and 2 are shown in Figure 2. The trends mentioned previously are readily apparent.

The data for the sidestream particulate phase are given in Table 3. This table also includes "free burn" data taken by using one lighting puff on a cigarette and allowing the remainder to smolder down to the butt line. Total particulate matter, condensate and nicotine deliveries increase slightly with increasing ventilation while particulate water decreases slightly.

Sidestream vapor phase data are given in Table 4 to correspond to the particulate phase data in Table 3. Carbon monoxide and nicotine in the sidestream appear to increase somewhat with ventilation while there is a definite increase in carbon dioxide. Water delivered to the sidestream vapor does not appear to be affected by ventilation.

Regression equation plots of the data from Tables 3 and 4 are shown in Figure 3. Taken together, it is clear that the total amount of material appearing in the sidestream increases with increasing ventilation. This is an obvious consequence of more tobacco being consumed in the puff interval relative to the puff itself.

Some comparisons can be made between the results of this study and other work, particularly that of Neurath et al. (9) with water distribution and Johnson et al. (4) with the distribution of combustion gases. These comparisons must be made with caution since this study was done with filter cigarettes while the other work was done with plain cigarettes. Taking data from Tables 1 to 4 , it can be shown that water is distributed $90 \%$ to $95 \%$ in favor of the sidestream which agrees with the Neurath (9) result. Calculation of sidestream/mainstream ratios for carbon monoxide and carbon dioxide for this study gives figures that agree well with the Jobnson (4) data for the Kentucky 1R1 blend. A comparison of $\mathrm{CO}_{2} / \mathrm{CO}$ ratios for mainstream and sidestream between this study and the other shows the ratios for this study to be about $25 \%$ lower than those found by Jobnson (4) for the Kentucky 1R1. This difference, which may be due to the smoking chamber configuration or the tobacco blend used or both, does not change the conclusion that sidestream combustion is more complete than mainstream (13). 
Figure 2. Calculated mainstream delivery as a function of dilution.

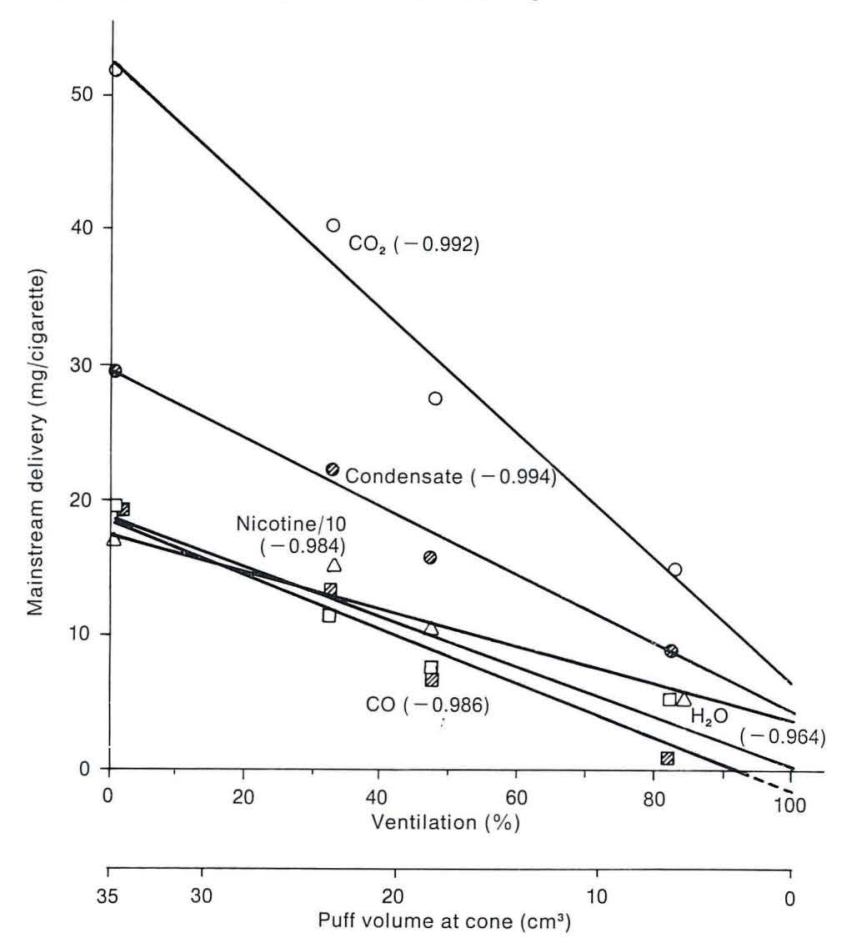

Table 1. Mainstream particulate phase data (including material captured on filters).

\begin{tabular}{|c|c|c|c|c|c|c|}
\hline Description & $\begin{array}{c}\text { Number } \\
\text { of } \\
\text { puffs }\end{array}$ & $\begin{array}{l}\text { Puff volume } \\
\text { at coal } \\
(\mathrm{ml})\end{array}$ & $\begin{array}{c}\text { Particulate } \\
\text { matter } \\
\text { (mg/cig.) }\end{array}$ & $\begin{array}{c}\text { Water } \\
\text { (mg/cig.) }\end{array}$ & $\begin{array}{l}\text { Nicotine } \\
\text { (mg/cig.) }\end{array}$ & $\begin{array}{c}\text { Condensate } \\
\text { (mg/cig.) }\end{array}$ \\
\hline \multicolumn{7}{|c|}{$35 \mathrm{ml}$ puff volume: } \\
\hline no dilution & 8.7 & 35.0 & 46.35 & 15.28 & 1.69 & 29.38 \\
\hline $33 \%$ dilution & 8.8 & 23.5 & 32.47 & 8.68 & 1.44 & 22.35 \\
\hline $48 \%$ dilution & 9.8 & 18.2 & 20.89 & 4.12 & 1.06 & 15.71 \\
\hline $83 \%$ dilution & 10.6 & 6.0 & 11.58 & 2.06 & 0.55 & 8.97 \\
\hline \multicolumn{7}{|c|}{$17.5 \mathrm{ml}$ puff volume: } \\
\hline no dilution & 9.6 & 17.5 & 29.35 & 6.71 & 1.19 & 21.45 \\
\hline $33 \%$ dilution & 10.3 & 11.7 & 18.55 & 4.65 & 0.89 & 13.01 \\
\hline \multicolumn{7}{|c|}{$50 \mathrm{ml}$ puff volume: } \\
\hline no dilution & 7.4 & 50 & 55.31 & 18.97 & 2.07 & 34.27 \\
\hline $33 \%$ dilution & 8.3 & 33.5 & 45.7 & 14.15 & 1.79 & 29.76 \\
\hline
\end{tabular}

Table 2. Mainstream vapor phase data.

\begin{tabular}{|c|c|c|c|c|c|c|}
\hline Description & $\begin{array}{c}\text { Number } \\
\text { of } \\
\text { puffs }\end{array}$ & $\begin{array}{l}\text { Puff volume } \\
\text { at coal } \\
(\mathrm{ml})\end{array}$ & $\begin{array}{c}\mathrm{CO} \\
\text { (mg/cig.) }\end{array}$ & $\begin{array}{c}\mathrm{CO}_{2} \\
\text { (mg/cig.) }\end{array}$ & $\begin{array}{c}\text { Water } \\
\text { (mg/cig.) }\end{array}$ & $\begin{array}{l}\text { Nicotine } \\
\text { (mg/cig.) }\end{array}$ \\
\hline \multicolumn{7}{|c|}{$35 \mathrm{ml}$ puff volume: } \\
\hline no dilution & 8.7 & 35 & 18.6 & 52.2 & 4.17 & .01 \\
\hline $33 \%$ dilution & 8.8 & 23.5 & 12.9 & 40.3 & 2.40 & .01 \\
\hline $48 \%$ dilution & 9.8 & 18.2 & 6.6 & 27.4 & 2.88 & .01 \\
\hline $83 \%$ dilution & 10.6 & 6.0 & 2.4 & 14.7 & 3.23 & .00 \\
\hline \multicolumn{7}{|c|}{$17.5 \mathrm{ml}$ puff volume: } \\
\hline no dilution & 9.6 & 17.5 & 9.3 & 32.4 & 2.21 & .00 \\
\hline $33 \%$ dilution & 10.3 & 11.7 & 5.0 & 22.2 & 1.48 & .00 \\
\hline \multicolumn{7}{|c|}{$50 \mathrm{ml}$ puff volume: } \\
\hline no dilution & 7.4 & 50.0 & 20.4 & 56.9 & 5.98 & .04 \\
\hline $33 \%$ dilution & 8.3 & 33.5 & 17.0 & 51.3 & 4.28 & .03 \\
\hline
\end{tabular}


Figure 3. Calculated sidestream delivery as a function of dilution.

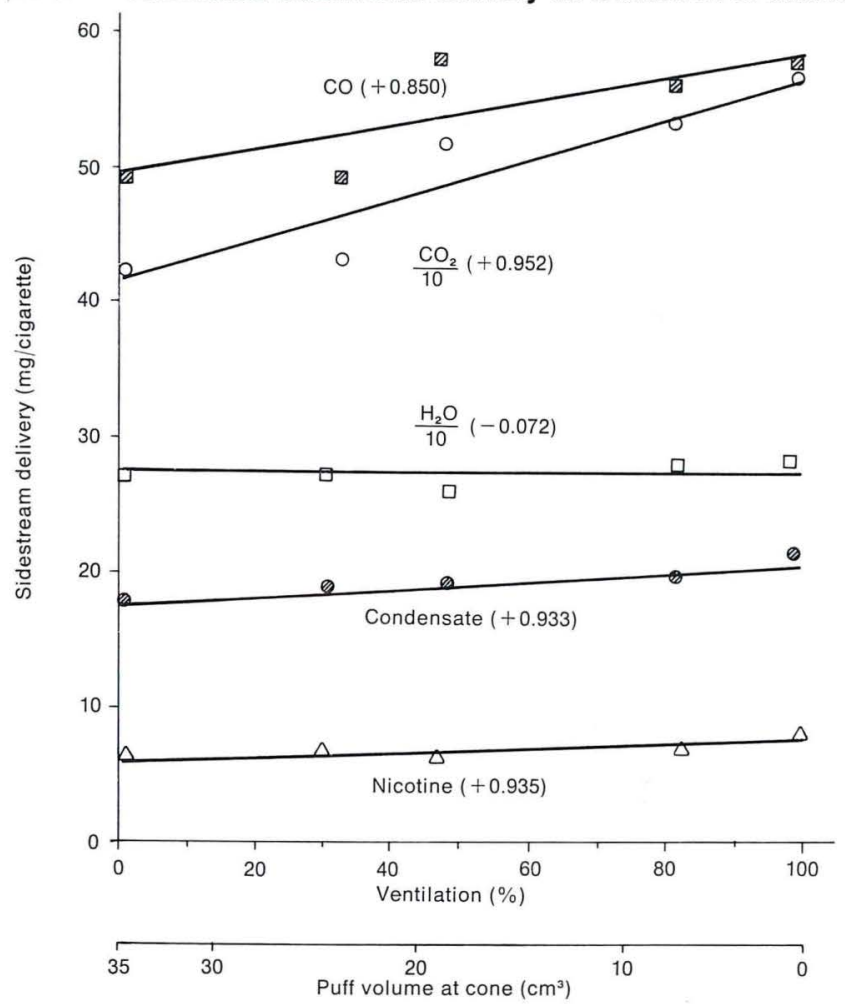

Table 3. Sidestream particulate phase data.

\begin{tabular}{|c|c|c|c|c|c|c|}
\hline Description & $\begin{array}{c}\text { Number } \\
\text { of } \\
\text { puffs }\end{array}$ & $\begin{array}{l}\text { Puff volume } \\
\text { at coal } \\
\text { (ml) }\end{array}$ & $\begin{array}{l}\text { Particulate } \\
\text { matter } \\
\text { (mg/cig.) }\end{array}$ & $\begin{array}{c}\text { Water } \\
\text { (mg/cig.) }\end{array}$ & $\begin{array}{l}\text { Nicotine } \\
\text { (mg/cig.) }\end{array}$ & $\begin{array}{c}\text { Condensate } \\
\text { (mg/cig.) }\end{array}$ \\
\hline \multicolumn{7}{|c|}{$35 \mathrm{ml}$ puff volume: } \\
\hline no dilution & 8.7 & 35 & 19.72 & 1.19 & .97 & 17.55 \\
\hline $33 \%$ dilution & 8.8 & 23.5 & 21.11 & 1.25 & 1.07 & 18.79 \\
\hline $48 \%$ dilution & 9.8 & 18.2 & 21.08 & 1.00 & 1.12 & 18.96 \\
\hline $83 \%$ dilution & 10.6 & 6.0 & 21.09 & 0.89 & 1.01 & 19.19 \\
\hline Free burn & 0.0 & 0.0 & 23.40 & 0.67 & 1.32 & 21.41 \\
\hline \multicolumn{7}{|c|}{$17.5 \mathrm{ml}$ puff volume: } \\
\hline no dilution & 9.6 & 17.5 & 22.61 & 1.17 & 1.13 & 20.31 \\
\hline $33 \%$ dilution & 10.3 & 11.7 & 20.30 & 1.01 & 0.98 & 18.31 \\
\hline \multicolumn{7}{|c|}{$50 \mathrm{ml}$ puff volume: } \\
\hline no dilution & 7.4 & 50 & 21.27 & 1.40 & 1.23 & 18.64 \\
\hline $33 \%$ dilution & 8.3 & 33.5 & 21.82 & 0.93 & 1.06 & 19.83 \\
\hline
\end{tabular}

Table 4. Sidestream vapor phase data.

\begin{tabular}{|c|c|c|c|c|c|c|}
\hline Description & $\begin{array}{c}\text { Number } \\
\text { of } \\
\text { puffs }\end{array}$ & $\begin{array}{l}\text { Puff volume } \\
\text { at coal } \\
\text { (ml) }\end{array}$ & $\begin{array}{c}\mathrm{CO} \\
\text { (mg/cig.) }\end{array}$ & $\begin{array}{c}\mathrm{CO}_{2} \\
\text { (mg/cig.) }\end{array}$ & $\begin{array}{c}\text { Water } \\
\text { (mg/cig.) }\end{array}$ & $\begin{array}{l}\text { Nicotine } \\
\text { (mg/cig.) }\end{array}$ \\
\hline \multicolumn{7}{|c|}{$35 \mathrm{ml}$ puff volume: } \\
\hline no dilution & 8.7 & 35 & 49.6 & 421.7 & 277.4 & 4.97 \\
\hline $33 \%$ dilution & 8.8 & 23.5 & 49.3 & 430.1 & 272.2 & 5.66 \\
\hline $48 \%$ dilution & 9.8 & 18.2 & 58.4 & 520.4 & 256.8 & 5.24 \\
\hline $83 \%$ dilution & 10.6 & 6.0 & 56.3 & 536.4 & 274.9 & 5.89 \\
\hline Free burn & 0.0 & 0.0 & 58.1 & 571.0 & 281.3 & 6.38 \\
\hline \multicolumn{7}{|c|}{$17.5 \mathrm{ml}$ puff volume: } \\
\hline no dilution & 9.6 & 17.5 & 63.0 & 546.5 & 238.9 & 5.43 \\
\hline $33 \%$ dilution & 10.3 & 11.7 & 62.2 & 598.0 & 212.4 & 6.05 \\
\hline \multicolumn{7}{|c|}{$50 \mathrm{ml}$ puff volume: } \\
\hline no dilution & 7.4 & 50 & 56.4 & 438.7 & 195.0 & 4.89 \\
\hline $33 \%$ dilution & 8.3 & 33.5 & 56.7 & 448.4 & 233.6 & 5.15 \\
\hline
\end{tabular}


Figure 4. Calculated total delivery as a function of dilution.

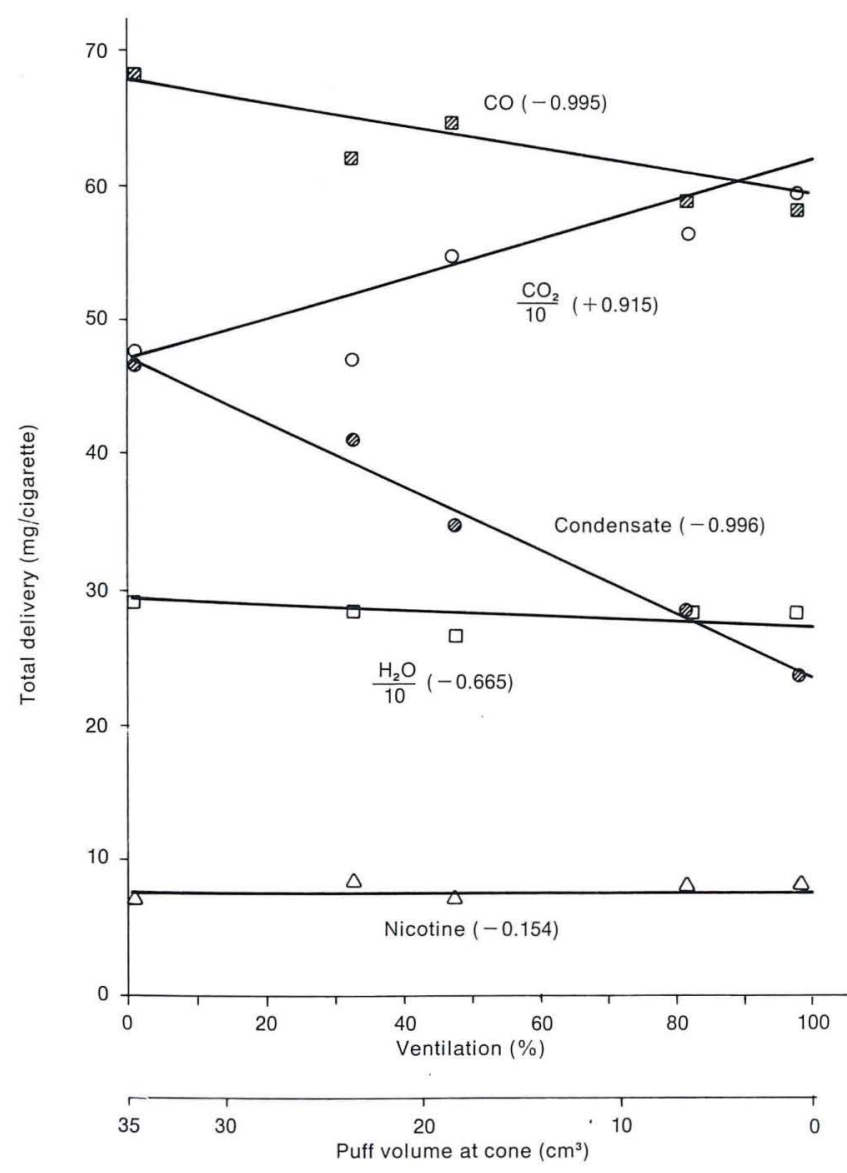

When all the mainstream and sidestream delivery data are summed (Table 5), several trends are immediately apparent. First, the puff count and puff volume show the expected inverse relationship whether the puff volume is a result of dilution of a $35 \mathrm{ml}$ puff or some other combination of puff volume and dilution. Second, the total amount of dry condensate produced is cut in half as the combustion process changes from undiluted puffing plus free burn to total free burn. Third, the same change in combustion mode results in about a $20 \%$ increase in total carbon dioxide production. Fourth, there is also a concommitant reduction of about $15 \%$ in total carbon monoxide. The reductions in condensate and carbon monoxide coupled with the increase in carbon dioxide are compelling evidence for a more efficient combustion process during free burn or smoldering. Fifth, the total deliveries of both nicotine and water which are mainly products of distillation and pyrolysis are essentially unchanged as a result of filter ventilation. These trends are also very clear in the plots of the regression equations shown in Figure 4 which are based on the data in Table 5 .

The decreases in the deliveries of the major mainstream components due to ventilation do not result in a strong shift of combustion products to the sidestream with the exception of carbon dioxide. Condensate, nicotine and water in the sidestream remain essentially constant while carbon monoxide goes up by $13 \%$ and carbon dioxide jumps up by $35 \%$. This is shown by Figures 2 and 3 .

As mentioned in the discussion, the data in Tables 1-5 were used to derive regression equations for the mainstream, sidestream and total deliveries of the major smoke components as a function of the degree of dilution. These equations are given in Table 6. Only those data points taken based on dilution of the standard $35 \mathrm{ml}$ puff were used in the calculations.

The equations describing mainstream component deliveries all show correlation at the $1 \%$ level of statistical significance. The sidestream equations show significance at the $1 \%$ level for condensate, nicotine and $\mathrm{CO}_{2}$. Sidestream $\mathrm{CO}$ correlation is at the $5 \%$ level while there is little correlation of sidestream water with level of dilution. Summing the two streams: condensate, $\mathrm{CO}$ and $\mathrm{CO}_{2}$ correlate at the $1 \%$ level, water at the $5 \%$ level but total nicotine shows little dependence on dilution.

The mainstream delivery equations of Table 6 were used to calculate the predicted deliveries and delivery ratios shown in Table 7 . The condensate/nicotine ratio decreases slightly with ventilation but the amount of condensate delivered increases with dilution relative to the main combustion products $\mathrm{CO}, \mathrm{CO}_{2}$ and water. The increases in the condensate/water and condensate/CO ratios are large

Table 5. Total delivery (mainstream and sidestream).

\begin{tabular}{|c|c|c|c|c|c|c|c|}
\hline Description & $\begin{array}{c}\text { Number } \\
\text { of } \\
\text { puffs }\end{array}$ & $\begin{array}{l}\text { Puff volume } \\
\text { at coal } \\
\text { (ml) }\end{array}$ & $\begin{array}{l}\text { Conden- } \\
\text { sate } \\
\text { (mg/cig.) }\end{array}$ & $\begin{array}{c}\text { Water } \\
\text { (mg/cig.) }\end{array}$ & $\begin{array}{l}\text { Nicotine } \\
\text { (mg/cig.) }\end{array}$ & $\begin{array}{c}\mathrm{CO} \\
\text { (mg/cig.) }\end{array}$ & $\begin{array}{c}\mathrm{CO}_{2} \\
\text { (mg/cig.) }\end{array}$ \\
\hline \multicolumn{8}{|c|}{$35 \mathrm{ml}$ puff volume: } \\
\hline no dilution & 8.7 & 35 & 46.9 & 298.0 & 7.64 & 68.2 & 473.9 \\
\hline $33 \%$ dilution & 8.8 & 23.5 & 41.1 & 284.5 & 8.18 & 62.2 & 470.4 \\
\hline $48 \%$ dilution & 9.8 & 18.2 & 34.7 & 264.8 & 7.43 & 65.0 & 547.8 \\
\hline $83 \%$ dilution & 10.6 & 6.0 & 28.2 & 280.7 & 7.45 & 58.7 & 551.1 \\
\hline Free burn & 0.0 & 0.0 & 23.40 & 282.0 & 7.70 & 58.1 & 571.0 \\
\hline \multicolumn{8}{|c|}{$17.5 \mathrm{ml}$ puff volume: } \\
\hline no dilution & 9.6 & 17.5 & 41.8 & 249.0 & 7.75 & 72.3 & 578.9 \\
\hline $33 \%$ dilution & 10.3 & 11.7 & 31.3 & 219.5 & 7.92 & 67.2 & 620.2 \\
\hline \multicolumn{8}{|c|}{$50 \mathrm{ml}$ puff volume: } \\
\hline no dilution & 7.4 & 50 & 52.9 & 221.4 & 8.23 & 76.8 & 495.6 \\
\hline $33 \%$ dilution & 8.3 & 33.5 & 49.6 & 253.0 & 8.03 & 73.7 & 499.7 \\
\hline
\end{tabular}


Table 6. Regression equations.

\section{Mainstream:}

$\begin{array}{lll}\text { Condensate }^{*} & 29.4 \\ \text { Nicotine } & =1.73 \\ \text { Water } & = & 18.8 \\ \mathrm{CO} & = & 18.5 \\ \mathrm{CO}_{2} & =52.4\end{array}$

$\begin{array}{ll}-25.1 D^{* *} & -0.994 \\ -1.4 D & -0.984 \\ -18.8 D & -0.964 \\ -20.4 D & -0.986 \\ -46.0 D & -0.992\end{array}$

Sidestream:

$\begin{array}{lll}\text { Condensate } & = & 17.5 \\ \text { Nicotine } & = & 5.94 \\ \text { Water } & = & 277 \\ \mathrm{CO} & = & 49.6 \\ \mathrm{CO}_{2} & =418.2\end{array}$

$$
+3.1 \mathrm{D}
$$$$
+0.933
$$$$
+1.5 \mathrm{D}
$$$$
-0.9 \mathrm{D}
$$$$
+9.0 \mathrm{D}
$$$$
+149.8 \mathrm{D}
$$

$-0.072$

$+0.850$

$+0.952$

\section{Total Smoke:}

$\begin{array}{llll}\text { Condensate } & =47.1 & -23.3 \mathrm{D} & -0.996 \\ \text { Nicotine } & =7.70 & -0.1 \mathrm{D} & -0.154 \\ \text { Water } & =294 & -20 \mathrm{D} & -0.665 \\ \mathrm{CO} & =68.0 & -10.3 \mathrm{D} & -0.995 \\ \mathrm{CO}_{2} & =471 & +100 \mathrm{D} & +0.915\end{array}$

* All components expressed as $\mathrm{mg} /$ cigarette.

** D: fractional dilution for $35 \mathrm{ml}$ puff.

compared to the condensate $/ \mathrm{CO}_{2}$ increase. This may be due to relatively greater diffusional losses with the smaller gas molecules. The change in the $\mathrm{CO}_{2} / \mathrm{CO}$ ratio is larger than can be accounted for by differences in rates of outward diffusion and so probably reflects a large offsetting effect from the changes in the combustion process. These equations are plotted in Figures 2, 3 and 4.

Tables 8 and 9 show mainstream and sidestream deliveries per gram of tobacco consumed during puffing and resting, respectively. The distribution of tobacco consumption between puffing and smoldering was estimated by means of nicotine delivery to the sidestream rather than by gravimetric means (4). The sidestream nicotine delivery resulting from free-burn or smoldering of the tobacco column from lighting puff down to the butt line and the weight of tobacco column consumed are the needed data. The tobacco consumed in smoldering during the puff intervals of a smoking experiment can then be determined by proportion knowing the sidestream nicotine delivered in that experiment. The corresponding amount of tobacco consumed during puffing is arrived at by difference.

Sidestream deliveries (Table 9) of the major components do not appear to change with ventilation on a per gram of tobacco consumed basis. The same is true for mainstream deliveries (Table 8) of condensate, nicotine and carbon dioxide. However, the mainstream deliveries of carbon monoxide and water on a per gram of tobacco basis appear to decrease significantly. This decrease may result from increased outward diffusion of these small gas molecules at the lower stream velocities resulting from dilution.

There is a considerable overall difference between the mainstream and sidestream, in delivery of the various materials per gram of tobacco burned. Table 10 shows that the condensate coming from the burning tobacco is largely destroyed during sidestream combustion, while nicotine and carbon monoxide are decreased to about $3 / 4$ of the mainstream values. The sidestream nicotine destruction agrees with that found by Johnson (4). The final combustion products, $\mathrm{CO}_{2}$ and water, are clearly enhanced in the sidestream, although the increase in the latter may be magnified by butt filtration of the mainstream water vapor.

\section{CONCLUSIONS}

1. Air dilution changes the burning process in cigarettes. The greater the dilution, the more the burning is like static burning. This results in less total condensate and carbon monoxide and in more carbon dioxide.

2. Changing the amount of dilution is comparable to changing the puff volume in the smoking cycle, and deliveries of most components are correlated with the puff volume at the coal.

3. Increasing air dilution decreases the deliveries of all mainstream components in a linear fashion, but not in comparable amounts. Greater air dilution gives more nicotine, less carbon monoxide and water but about the same amount of carbon dioxide relative to condensate in the mainstream.

4. As air dilution is increased, the sidestream smoke contains relatively constant amounts of distillable com-

Table 7. Predicted mainstream deliveries ( $\mathrm{mg} /$ cigarette) and delivery ratios.

\begin{tabular}{|c|c|c|c|c|c|}
\hline Dilution & Condensate & Nicotine & Water & $\mathrm{CO}$ & $\mathrm{CO}_{2}$ \\
\hline 0 & 29.4 & 1.73 & 18.8 & 18.5 & 52.4 \\
\hline 25 & 23.1 & 1.38 & 14.1 & 13.4 & 40.9 \\
\hline 50 & 16.9 & 1.03 & 9.4 & 8.3 & 29.4 \\
\hline 75 & 10.6 & 0.68 & 4.7 & 3.2 & 17.9 \\
\hline Dilution & Condensate/Nicotine & Condensate/Water & Condensate/CO & Condensate $/ \mathrm{CO}_{2}$ & $\mathrm{CO}_{2} / \mathrm{CO}$ \\
\hline 0 & 17.0 & 1.56 & 1.59 & 0.561 & 2.83 \\
\hline 25 & 16.7 & 1.64 & 1.72 & 0.567 & 3.05 \\
\hline 50 & 16.4 & 1.80 & 2.04 & 0.575 & 3.54 \\
\hline 75 & 15.6 & 2.26 & 3.31 & 0.592 & 5.59 \\
\hline
\end{tabular}


Table 8. Mainstream deliveries per gram of tobacco burnt during puffing $(\mathrm{mg} / \mathrm{g})$.

\begin{tabular}{|c|c|c|c|c|c|c|}
\hline Description & $\begin{array}{l}\text { Puff volume } \\
\text { at coal (ml) }\end{array}$ & Condensate & Water & Nicotine & $\mathrm{CO}$ & $\mathrm{CO}_{2}$ \\
\hline \multicolumn{7}{|l|}{$35 \mathrm{ml}$ puff volume: } \\
\hline no dilution & 35 & 239 & 158 & 13.8 & 151 & 424 \\
\hline $33 \%$ dilution & 23.5 & 251 & 124 & 16.3 & 145 & 453 \\
\hline $48 \%$ dilution & 18.2 & 212 & 95 & 14.4 & 89 & 370 \\
\hline $83 \%$ dilution & 6 & 236 & 139 & 14.5 & 63 & 387 \\
\hline \multicolumn{7}{|l|}{$17.5 \mathrm{ml}$ puff volume: } \\
\hline no dilution & 17.5 & 298 & 124 & 16.5 & 129 & 450 \\
\hline $33 \%$ dilution & 11.7 & 236 & 111 & 16.2 & 91 & 404 \\
\hline \multicolumn{7}{|l|}{$50 \mathrm{ml}$ puff volume: } \\
\hline no dilution & 50 & 205 & 149 & 12.6 & 122 & 341 \\
\hline $33 \%$ dilution & 33.5 & 250 & 155 & 15.3 & 143 & 431 \\
\hline Average & & 241 & 137 & 14.7 & 124 & 411 \\
\hline Standard deviation & & 25 & 23 & 1.3 & 32 & 36 \\
\hline Coefficient of variation & & $10.4 \%$ & $16.5 \%$ & $8.9 \%$ & $25.6 \%$ & $8.7 \%$ \\
\hline
\end{tabular}

Table 9. Sidestream deliveries per gram of tobacco burnt during resting $(\mathbf{m g} / \mathbf{g})$.

\begin{tabular}{|c|c|c|c|c|c|c|}
\hline Description & $\begin{array}{l}\text { Puff volume } \\
\text { at coal (ml) }\end{array}$ & Condensate & Water & Nicotine & $\mathrm{CO}$ & $\mathrm{CO}_{2}$ \\
\hline \multicolumn{7}{|l|}{$35 \mathrm{ml}$ puff volume: } \\
\hline no dilution & 35 & 31.6 & 501 & 10.7 & 89.2 & 758 \\
\hline $33 \%$ dilution & 23.5 & 31.8 & 464 & 11.4 & 83.6 & 729 \\
\hline $48 \%$ dilution & 18.2 & 31.3 & 426 & 10.5 & 96.5 & 860 \\
\hline $83 \%$ dilution & 6 & 29.9 & 430 & 10.8 & 87.8 & 837 \\
\hline \multicolumn{7}{|l|}{$17.5 \mathrm{ml}$ puff volume: } \\
\hline no dilution & 17.5 & 33.5 & 396 & 10.8 & 104 & 900 \\
\hline $33 \%$ dilution & 11.7 & 29.3 & 342 & 12.8 & 100 & 958 \\
\hline \multicolumn{7}{|l|}{$50 \mathrm{ml}$ puff volume: } \\
\hline no dilution & 50 & 36.4 & 384 & 12.0 & 110 & 857 \\
\hline $33 \%$ dilution & 33.5 & 35.4 & 418 & 11.1 & 101 & 801 \\
\hline Free burn & 0 & 35.5 & 428 & 11.7 & 88.2 & 866 \\
\hline Average & & 32.5 & 436 & 11.2 & 94.4 & 826 \\
\hline Standard deviation & & 2.3 & 52 & .7 & 8.3 & 71 \\
\hline Coefficient of variation & & $7.2 \%$ & $12.0 \%$ & $6.3 \%$ & $8.8 \%$ & $8.6 \%$ \\
\hline
\end{tabular}

Table 10. Comparison of sidestream and mainstream combustion products on a per gram of tobacco consumed basis.

\begin{tabular}{lc|c|c|c|c}
\cline { 2 - 6 } & Condensate & Nicotine & $\begin{array}{c}\text { Carbon } \\
\text { monoxide }\end{array}$ & $\begin{array}{c}\text { Carbon } \\
\text { dioxide }\end{array}$ & Water \\
\hline Sidestream & $32.5 \mathrm{mg}$ & $11.2 \mathrm{mg}$ & $94.4 \mathrm{mg}$ & $826 \mathrm{mg}$ & $436 \mathrm{mg}$ \\
Mainstream & $241.0 \mathrm{mg}$ & $14.7 \mathrm{mg}$ & $124.0 \mathrm{mg}$ & $411 \mathrm{mg}$ & $137 \mathrm{mg}$ \\
Sidestream & $13.5 \%$ & $76 \%$ & $76 \%$ & $200 \%$ & $318 \%$ \\
\hline Mainstream & 100 & & & & \\
\hline
\end{tabular}


ponents such as water, nicotine and condensate, but carbon monoxide and carbon dioxide increase, the latter much more markedly than the former.

5. When deliveries are expressed in terms of amount per gram of tobacco burned during puffing or resting, the delivery of all sidestream components is essentially constant as dilution is changed. In the mainstream, condensate, nicotine and carbon dioxide appear to be constant on this basis, while carbon monoxide and water appear to decrease as dilution increases. These results are consistent with the greater loss of gases through diffusion and the changing combustion pattern as dilution is raised.

6. Sidestream combustion yields $13.5 \%$ of the condensate, $76 \%$ of the nicotine, $76 \%$ of the carbon monoxide, $200 \%$ of the carbon dioxide and $318 \%$ of the water formed in mainstream combustion (Table 10). Correction of these gas phase values for diffusion losses would further reduce these percentages, as would correction for butt filtration of water.

\section{SUMMARY}

Apparatus and procedures were developed to measure condensate, nicotine, water, carbon monoxide and carbon dioxide in mainstream and sidestream smoke. These were used to determine the effect of air dilution through filter ventilation on mainstream and sidestream smoke composition. It was found that there is a gradual transition from puffing combustion to smoldering combustion as the amount of diluting air entering the system increases. This is directly related to the decreased puff volume at the cone and decreased amount of tobacco consumed per puff. On a per gram of tobacco consumed basis, sidestream combustion product formation is not changed but the amounts of carbon monoxide and water in the mainstream are decreased, as ventilation increases.

\section{ZUSAMMENFASSUNG}

Mit einem von den Autoren entwickelten Verfahren zur Messung von Kondensat, Nikotin und Wasser sowie Kohlenmonoxid und Kohlendioxid in Haupt- und Nebenstromrauch wurde untersucht, welchen Einfluß die durch Filterventilation bewirkte Verdünnung des Rauchstromes mit Luft auf die Zusammensetzung von Haupt- und Nebenstromrauch ausübt. Es zeigte sich, daß mit zunehmender Ventilation in den Filter die während des Zuges verrauchte Tabakmenge abnimmt und die zwischen den Zügen verglimmte Tabakmenge entsprechend zunimmt. Dies erklärt sich unmittelbar aus dem verkleinerten Zugvolumen hinter der Glutzone, welches seinerseits eine Erniedrigung der während des Zuges verbrannten Tabakmenge nach sich zieht. Bezogen auf ein Gramm verbrannten Tabaks, führte die Steigerung der Ventilation zwar zu einer Verminderung des Gehaltes des Hauptstromrauches an Kohlenmonoxid und Wasser, nicht aber zu einer Veränderung in der Bildung der Verbrennungsprodukte des Nebenstromrauches.

\section{RÉSUMÉ}

Un appareil et des procédés ont été mis au point pour déterminer le condensat, la nicotine, l'eau, le monoxide de carbone et le dioxide de carbone dans les fumées principale et secondaire. On a étudié l'effet de la dilution par les filtres ventilés sur la composition des fumées principale et secondaire. Avec l'augmentation du flux d'air entrant dans le filtre, on observe une transition progressive de la combustion «pendant les bouffées» vers la combustion «entre les bouffées». Ceci est en corrélation directe avec la diminution du volume de bouffée au niveau du cône de combustion et avec la diminution de la quantité de tabac consumé par bouffée. Par rapport au gramme de tabac consumé, la formation des produits de combustion dans la fumée secondaire ne subit pas de changement du fait de l'augmentation de la ventilation, mais celle-ci provoque une diminution des quantités de monoxide de carbone et d'eau dans la fumée principale.

\section{REFERENCES}

1. Schur, M. O., and J. C. Rickards: The design of low yield cigarettes; Tobacco Science 4 (1960) 69-77.

2. Lipp, G., and H. van Nooy: Neue Methoden zur Messung der Porosität von Cigarettenpapier und des Ventilationsgrades von Cigaretten; Beitr. Tabakforsch. 1 (1962) 369-384.

3. Müller, K.-H., G. Neurath and H. Horstmann: Einfluß der Luftdurchlässigkeit von Cigarettenpapier auf die Ausbeute und Zusammensetzung des Rauches; Beitr. Tabakforsch. 2 (1964) 271-281.

4. Johnson, W. R., R. W. Hale, J. W. Nedlock, H. J. Grubbs, and D. H. Powell: The distribution of products between mainstream and sidestream smoke; Tobacco Science 17 (1973) 141-144.

5. Norman, V.: The effect of perforated tipping paper on the yield of various smoke components; Beitr. Tabakforsch 7 (1974) 282-287.

6. Morie, G. P., and C. H. Sloan: The use of cryogenic temperature gas chromatography for the determination of carbon monoxide and carbon dioxide in cigarette smoke; Beitr. Tabakforsch. 6 (1972) 178-181.

7. Morie, G. P.: The use of Carbosieve-B chromatography packing for the determination of $\mathrm{CO}$ and $\mathrm{CO}_{2}$ in cigarette smoke; Tobacco Science 17 (1973) 125126.

8. Morie, G. P.: Some factors that affect the diffusion of carbon monoxide out of cigarettes; Tobacco Science 20 (1976) 174-176.

9. Neurath, G., H. Ehmke, and H. Schneemann: Über den Wassergehalt von Haupt- und Nebenstromrauch; Beitr. Tabakforsch. 3 (1966) 351-357.

10. Ogg, C. L., and E. F. Schultz: Collaborative study of the determination of tar and nicotine in cigarette smoke; J. Ass. Off. Anal. Chem. 53 (1972) 659-672.

11. Watanabe, M., and Y. Kobashi: Analytical methods of chemical components in tobacco smoke, I. Determination of carbon monoxide and carbon dioxide in 
cigarette smoke by gas chromatography; Scientific Paper No.107, Central Research Institute, Japan Monopoly Corporation, pp. 177-180, 1965.

12. Newsome, J. R., and C. H. Keith: Quantitative studies on cigarette smoke, II. The effect of physical variables on the weight of smoke; Tobacco Science 1 (1957) 58-63.

13. Harlan, W. R., and J. M. Moseley: Tobacco, in: Encyclopedia of Chemical Technology, Vol. 14; McGraw-Hill, New York, 1955, 242-261.

14. Keith, C. H.: The use of pressure drop measurements for estimating ventilation and paper porosity; Paper
Presented at 31st Tobacco Chemists' Res. Conf., Greensboro, N. C., October 1977.

15. Baker, R. R., and R. A. Crellin: The diffusion of carbon monoxide out of cigarettes; Beitr. Tabakforsch. 9 (1977) 131-140.

Authors' address:

Celanese Fibers Company,

Box 32414,

Charlotte, North Carolina, 28232, U.S.A. 